\title{
Correction: The Prevalence of Asymptomatic Bacteriuria in Iranian Pregnant Women: A Systematic Review and Meta-Analysis
}

Mahin Ghafari, Vali Baigi, Zahra Cheraghi, Amin Doosti-Irani

Fig 1 is incorrect. Records excluded $(\mathrm{n}=3342)$ is wrong. The records excluded should be $(\mathrm{n}=3442)$. The authors have provided a corrected version here.

G openaccess

Citation: Ghafari M, Baigi V, Cheraghi Z, DoostiIrani A (2016) Correction: The Prevalence of Asymptomatic Bacteriuria in Iranian Pregnant Women: A Systematic Review and Meta-Analysis. PLOS ONE 11(10): e0165114. doi:10.1371/journal. pone. 0165114

Published: October 18, 2016

Copyright: @ 2016 Ghafari et al. This is an open access article distributed under the terms of the Creative Commons Attribution License, which permits unrestricted use, distribution, and reproduction in any medium, provided the original author and source are credited. 


\section{PRISMA 2009 Flow Diagram}

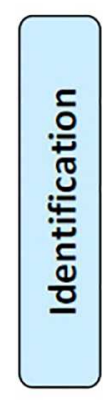

Records identified through international database searching

( $n=3647$ )
Additional records identified through other sources

$$
(n=62)
$$

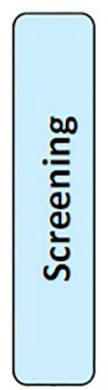

Records after duplicates removed

$(n=3501)$
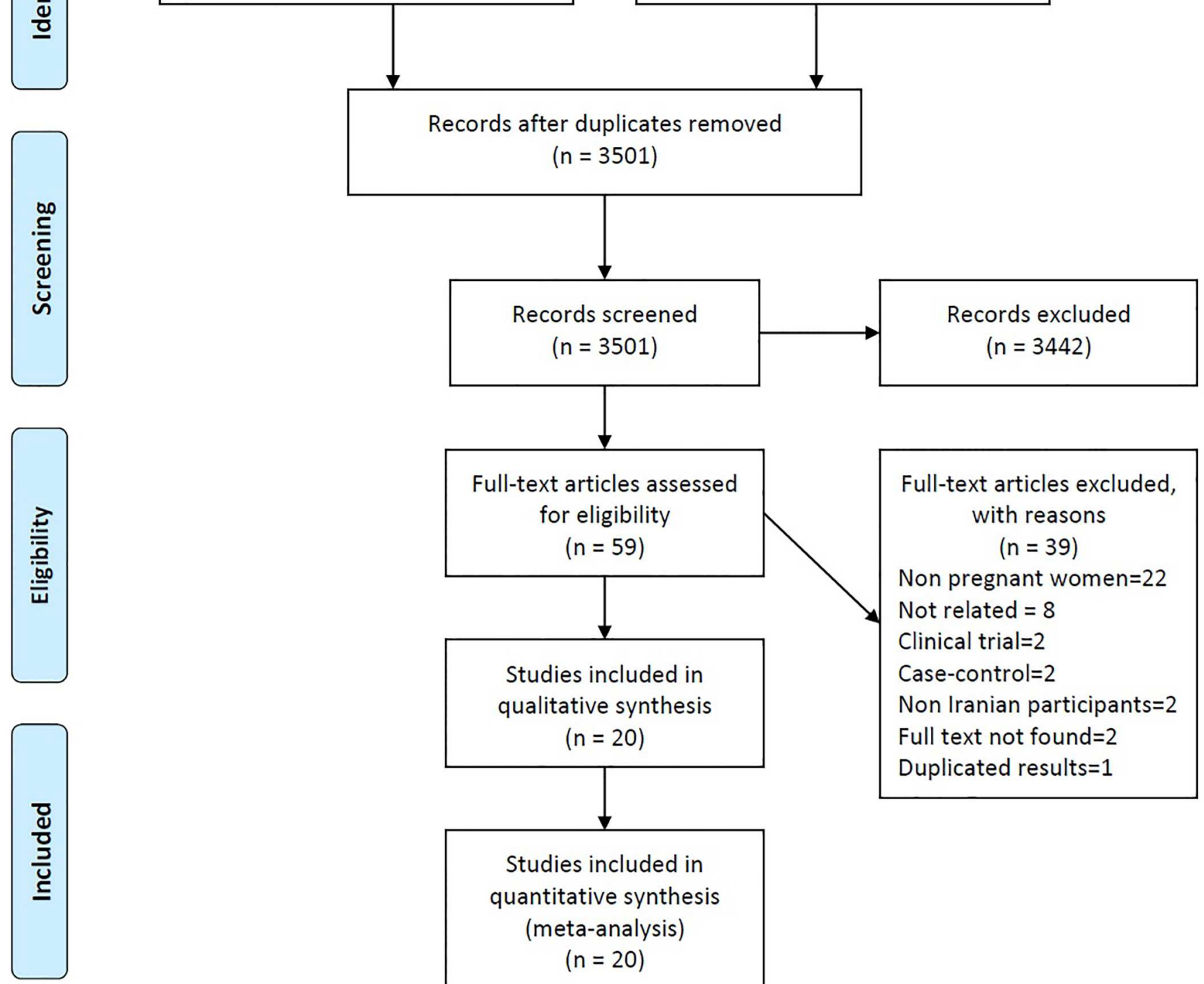

Studies included in quantitative synthesis

(meta-analysis) $(n=20)$

Fig 1. A flow chart depicting the stages of retrieving articles and checking eligibility criteria for meta-analysis. From: Moher $D$, Liberati $A$, Tetzlaff J, Altman DG, The PRISMA Group (2009). Preferred Reporting /tems for Systematic Reviews and Meta-Analyses: The PRISMA Statement. PLoS Med 6(7): e1000097. doi:10.1371/journal.pmed1000097. For more information, visit www.prisma-statement.org.

doi:10.1371/journal.pone.0165114.g001 


\section{Reference}

1. Ghafari M, Baigi V, Cheraghi Z, Doosti-Irani $A$ (2016) The Prevalence of Asymptomatic Bacteriuria in Iranian Pregnant Women: A Systematic Review and Meta-Analysis. PLoS ONE 11(6): e0158031. doi: 10.1371/journal.pone.0158031 PMID: 27336476 